\title{
EFFECTS OF GA 3 AND ABA ON THE GERMINATION OF DORMANT OAT (AVENA SATIVA L.) SEEDS
}

\author{
GE, J. Y. ${ }^{1,2}-$ ZHANG, B. ${ }^{1}-$ KHAN, T. A. ${ }^{2}-$ WANG, X. $.^{1,2}-$ REN, Q. J. ${ }^{1}-$ JIA, P. F. ${ }^{2}-$ WANG, X. Y. ${ }^{1}$ \\ $-\mathrm{HU}, \mathrm{Y} . \mathrm{G}^{2 *}-\mathrm{REN}, \mathrm{C} . \mathrm{Z}^{3}$ \\ ${ }^{\text {I}}$ Zhangjiakou Academy of Agricultural Sciences, Zhangjiakou City, Hebei 075000, China \\ ${ }^{2}$ College of Agronomy and Biotechnology, China Agricultural University, Beijing 100193, \\ China \\ ${ }^{3}$ Baicheng Academy of Agricultural Sciences, Baicheng City, Jilin 137000, China \\ *Corresponding author \\ e-mail: gejy207@163.com,huyuegao@cau.edu.cn
}

(Received 22 $2^{\text {nd }}$ Mar 2019; accepted $4^{\text {th }}$ Jul 2019)

\begin{abstract}
The dormancy characteristics of oat seed that can germinate after one season or one year are used to build and maintain vegetation to protect soils from desertification in Northern China. The aim of this study was to estimate the effects of endogenous and exogenous $\mathrm{GA}_{3}$ and $\mathrm{ABA}$ on oat seed (Avena sativa L. BaiYan 7) germination. The results showed that seed without peel hull had lower endogenous $\mathrm{ABA}$ content and the ratio of $\mathrm{ABA} / \mathrm{GA}_{3}$ than seeds with peel hull. The best $\mathrm{GA}_{3}$ treatment duration for milky ripe, wax ripe, full ripe seeds were $60 \mathrm{~min}(\mathrm{~m})$ or $120 \mathrm{~m}, 60 \mathrm{~m}$ and $30 \mathrm{~m}$, respectively. Seed germination rate, germination potential and germination index all increased then decreased with the increasing of $\mathrm{GA}_{3}$ concentrations. The best $\mathrm{GA}_{3}$ concentration treatment was $100 \mathrm{mg} \mathrm{L}^{-1}$, while the turning point was $200 \mathrm{mg} \mathrm{L}^{-1}$. The dormancy rate of low temperature storage seeds was higher than those stored in room temperature at each storage time, and both decreased with the increase of the storage time. New seeds or stored for 1-2 months, had significantly enhanced germination rate by exogenous $\mathrm{GA}_{3}$. GA3 treatment had no effect on germination rate for the seeds that had been stored for over 3 months. Germination rate decreased with the increase of ABA concentrations. The most inhibitive effect, which lead to reduction of seed germination by $37.7 \%$ and $4.0 \%$, when the concentration of ABA was $500 \mathrm{mg} \mathrm{L}^{-1}$ and $1000 \mathrm{mg} \mathrm{L}^{-1}$, respectively. $\mathrm{GA}_{3}$ could decrease the inhibition effect of $\mathrm{ABA}$ on seed germination.
\end{abstract}

Keywords: oat, germination rate, gibberellic acid (GA3), abscisic acid ( $A B A)$ endogenous, exogenous

\section{Introduction}

China's desertification area is about 1.74 million $\mathrm{km}^{2}$, accounting for $18 \%$ of the total land area, and the area is going to increase in the future (Islam et al., 2011; Cheng et al., 2018). To solve this problem, it is important to build and maintain plant biology to increase surface coverage and restore native vegetation, which is the main reason why Chinese government has set up China Agriculture Research System to support the production and study of oat (Lin et al., 2012; Qian et al., 2018). Oat (Avena sativa L.) is a annual herbaceous plant belonging in gramineous precocious subfamily. It has strong ability to resist wind erosion and easy to sow, and easy to build plant (Lin et al., 2012; Zang et al., 2018). Oat can be cultivated in the marginal land with less water and fertilizer requirement so well adapted in desert area (Ren et al., 2007; Rabiei et al., 2012; Zang et al., 2015; Khan et al., 2019). Li et al. (2009) proved the strong antierosion ability of oat than corn, sunflower and mung bean, which will help to prevent farmland from desertification. "Baiyan7", breed by Baicheng Academy of Agricultural Sciences, has dormancy characteristics. Some other researches showed the dormancy strength of "Baiyan 7" can affect the vegetation establishment. Now the studies of oat 
planting have focused on breeding, cultivation, physiological and biochemical aspects, oat seed science research focuses on the germination optimum temperature, germination substrate, salinity stress and seed storage, but the researches about the effect of phytohormones on germination of dormant oat are quite few. It is an innate property of seed that defines the environmental conditions in which the seed is able to germinate. It is determined by genetics with a substantial environmental influence which is mediated, at least in part, by the plant hormones abscisic acid and gibberellins (Finch-Savage and Leubne, 2006). Many previous studies show that $\mathrm{GA}_{3}$ is the main regulator on seed germination and it could lift the bud and seed dormancy and promote bud instead of light or low temperature (Mukhtar and Singh, 2006; Ozkaya et al., 2006; Liu et al., 2016). Other study also found that for the germination of brown rice seed, in addition to water and a certain temperature, $\mathrm{GA}_{3}$ was a promoting substance of seed germination (Damaris et al., 2019). ABA is a phytohormone which has been shown to be involved in a wide range of plant physiology (Wilkinson and Davies, 2010; Zhang et al., 2017). ABA could inhibit seed germination requirement concentration varies.

Therefore, we aims to 1) estimate the best GA3 concentration and treat time for germination of oat seed with different maturity; 2) evaluate the oat seed germination as affected by ABA input; 3) test the combination effect of GA3 and ABA for oat seed germination.

\section{Materials and methods}

\section{Study site and materials}

The experiment was conducted at Baicheng Academy of Agricultural Sciences, Baicheng, Jilin province, China $\left(45^{\circ} 37^{\prime} \mathrm{N}, 122^{\circ} 48^{\prime} \mathrm{E}, 152 \mathrm{~m}\right.$ elevation). The detail information of experiment sites could be found in Zang et al., 2018 and Qian et al., 2018. Bai Yan 7 oat (Avena sativa L.) seed used in this experiment supplied by the Baicheng Academy of Agricultural Sciences. Part of the seeds collected immediately for germination test, and other stored at room temperature under dry conditions or at $4{ }^{\circ} \mathrm{C}$ refrigerator for later use.

\section{Experimental design}

\section{a) The effects of $\mathrm{GA}_{3}$ treat time on germination of oat seed with different maturity}

Each different matured oat seed were soaked in $100 \mathrm{mg} \mathrm{L}^{-1} \mathrm{GA}_{3}$ for different times in order to test the germination. The treatments time were $\mathrm{T} 1=0 \mathrm{~m}, \mathrm{~T} 2=30 \mathrm{~m}$, $\mathrm{T} 3=60 \mathrm{~m}, \mathrm{~T} 4=120 \mathrm{~m}$, and $\mathrm{T} 5=240 \mathrm{~m}$, different maturity were $\mathrm{S} 1=$ milky ripe, $\mathrm{S} 2=$ wax ripe, and $\mathrm{S} 3=$ full ripe. So the experiment had 15 treatment combinations, with three biological replications, and each replicates have 200 seeds. First, the seeds soaked and disinfected in $4.0 \%$ sodium hypochlorite solution for $30 \mathrm{~min}$, then washed 5-6 times with distilled water. Second, tweezers were used to put the seeds in Petri dishes lined with filter paper, each plate contained 200 seeds and were kept at sufficient distance. Third, the Petri dishes were placed in an incubator maintaining temperature $20{ }^{\circ} \mathrm{C}$, distilled water was used to keep the filter paper moist, sprout numbers in each treatment were recorded every morning, for 10 days, and the whole process were repeated 3 times. (These materials and methods are applicable to the following experiments.) 


\section{b) The effects of GA3 concentrations on wax ripe seed germination}

The wax ripe seeds were soaked in different $\mathrm{GA}_{3}$ concentrations for $120 \mathrm{~min}$, and then test the germination. Six treatments were established with increasing $\mathrm{GA}_{3}$ concentrations as $0,12.5,25,50,100$, and $200 \mathrm{mg} \mathrm{L}^{-1}$ (i.e. A1, A2, A3, A4, A5, and A6, respectively).

c) The effects of GA3 on germination of oat seed in different maturity with or without peel

Different maturities were cream ripe, wax ripe and full ripe. Each maturity seeds had four treatments: $\mathrm{B} 1=$ seeds with peel, $\mathrm{B} 2=$ seeds without peel, $\mathrm{B} 3=$ unpeeled seeds soaked in $\mathrm{GA}_{3}$ for $2 \mathrm{~h}, \mathrm{~B} 4=$ peeled seeds soaked in $\mathrm{GA}_{3}$ for $2 \mathrm{~h}$.

d) The effects of $\mathrm{GA}_{3}$ on germination of different matured oat seeds under low or room temperature

Oat seeds with different maturity were stored under low or room temperature. Different maturities were cream ripe, wax ripe and full ripe. Each kind of seeds had five storage durations: $0,1,2,3$, and 4 months (i.e. C1, C2, C3, C4, and C5).

\section{e) The interaction effect of GA3 and ABA on germination of oat seed}

$\mathrm{GA}_{3}$ and $\mathrm{ABA}$ were dissolved in a small amount of ethanol, constant volume with distilled water, $\mathrm{GA}_{3}$ preparation of $100 \mathrm{mg} \mathrm{L}^{-1}$, the $\mathrm{ABA} 1000 \mathrm{mg} \mathrm{L}^{-1}$ as stock solution, respectively, using the $\mathrm{GA}_{3}$ liquid and different concentrations of ABA dilution to deal with the sterilized seed, soak $30 \mathrm{~min}$, remove seeds, and dry with filter paper, then do germination test. For $\mathrm{GA}_{3}$ and $\mathrm{ABA}$ application, first the seed soak with different concentrations of ABA solution $30 \mathrm{~min}$, after that soak with $\mathrm{GA}_{3}$ solution for $30 \mathrm{~min}$, and then start germination test. This experiment has nine treatments: D1 $=1000 \mathrm{mg} \mathrm{L}^{-1}$ $\mathrm{ABA} ; \mathrm{D} 2=500 \mathrm{mg} \mathrm{L} \mathrm{L}^{-1} \mathrm{ABA} ; \mathrm{D} 3=250 \mathrm{mg} \mathrm{L}^{-1} \mathrm{ABA} ; \mathrm{D} 4=100 \mathrm{mg} \mathrm{L}^{-1}$ ABA; $\mathrm{D} 5=100 \mathrm{mg} \mathrm{L}^{-1} \mathrm{GA}_{3}+100 \mathrm{mg} \mathrm{L}^{-1} \mathrm{ABA} ; \mathrm{D} 6=100 \mathrm{mg} \mathrm{L}^{-1} \mathrm{GA}_{3}+250 \mathrm{mg} \mathrm{L}^{-1} \mathrm{ABA}$; $\mathrm{D} 7=100 \mathrm{mg} \mathrm{L}^{-1} \mathrm{GA}_{3}+500 \mathrm{mg} \mathrm{L}^{-1} \mathrm{ABA} ; \mathrm{D} 8=100 \mathrm{mg} \mathrm{L}^{-1} \mathrm{GA}_{3}+1000 \mathrm{mg} \mathrm{L}^{-1} \mathrm{ABA}$; CK use distilled water as control.

The detail experimental design of all experiment in present study also have been summarised as Table Al in the Appendix.

\section{Determination indexes and methods}

\section{a) Seed collection standard}

Oat seed development process was divided into three maturity phase. Full ripe: glumes white and open, the appearance of seed is yellowish-white, hard; wax ripe: glumes the sallow semi-open, the appearance of seed is yellow-green, slightly harder, volume reach mature state; milk ripe: glumes green and closed, the appearance of seed is green, tender, the volume does not reach mature state.

b) Determination of germination rate, germination potential, germinating, germination index and $T 50$

Test method reference to the international seed testing and GB/T2930.4-2001. 
Germinating refers to the ratio of the sum of the maximum number of germination within three days and total number of germination.

$\mathrm{T}_{50}$ refers to seed germination rate of the time required in half of the final germination.

$$
\text { Germination rate }(\%)=(\mathrm{n} / \mathrm{N}) \times 100
$$

In this equation $\mathrm{n}$ refers to the seed within the specified time normal germination accumulated grains, $\mathrm{N}$ refers to the total number of tested seeds.

$$
\text { Germination potential }(\%)=(\mathrm{A} / \mathrm{N}) \times 100
$$

In Equation 2, "A" refers to the cumulative germination rate of $3 \mathrm{~d}$ before the test.

$$
\text { Germination index }=\Sigma \mathrm{Gt} / \mathrm{Dt}
$$

In Equation 3, "Gt" refers to the number of germination of the time t, "Dt" refers to the germination days.

\section{Statistical analyses}

Experimental raw data use the Excel (2007 version) statistical software to collate, then use both SAS (8.0 version) and Mstate-C statistical software to analyse. A factorial layout within randomized complete block design with 3 replications was used to analysis the variation of $\mathrm{GA}_{3}$ processing time effect on germination characteristics of seeds in different maturity. Seed maturity were milky ripe seed, wax ripe seed and full ripe seed. $\mathrm{GA}_{3}$ processing times were included 0, 30, 60, 120 and $240 \mathrm{~min}$. In order to determine the influence of $\mathrm{GA}_{3}$ concentration on different experimental characteristics, a randomized complete block design with three replications were used. $\mathrm{GA}_{3}$ concentrations were $0,12.5,25,50,100$ and $200 \mathrm{mg} \mathrm{L}^{-1}$.

\section{Results and discussion}

As shown in Table 1, fully ripe seeds with or without peel, had significant differences $(p<0.05)$ in endogenous $\mathrm{GA}_{3}, \mathrm{ABA}$ and $\mathrm{GA}_{3} / \mathrm{ABA}$ at different storage periods. Endogenous $\mathrm{GA}_{3}$ in fully ripe seeds without peel in each storage period were significantly higher than those with peel $(\mathrm{p}<0.05)$. With the extension of storage time, endogenous $\mathrm{GA}_{3}$ in full ripe seeds without peel were increased by $68.7 \%, 121.4 \%$, $59.2 \%, 18.2 \%$, and $29.0 \%$, respectively when compared with seeds with peel. $\mathrm{GA}_{3}$ contents showed a tremendous increasing trend with the storage time. Endogenous ABA in full ripe seeds with peel in each storage period was significantly higher than that in the seeds without peel $(\mathrm{p}<0.05)$, with the extension of storage time, endogenous ABA in full ripe seed with peel than seed without peel were increased by $8.4 \%, 49.0 \%$, $37.7 \%, 74.5 \%$, and $36.7 \%$, respectively, which means that it contains a certain amount of $\mathrm{ABA}$ within the peel. The ratio of $\mathrm{GA}_{3} / \mathrm{ABA}$ in full ripe seeds without peel in each storage period was significantly higher than that in the seeds with peel $(p<0.05)$, with the extension of storage time, the ratio of $\mathrm{GA}_{3} / \mathrm{ABA}$ in full ripe seeds without peel than seed with peel were increased by $82.8 \%, 229.9 \%, 119.2 \%, 106.2 \%$, and $76.3 \%$, respectively (Table 1). 
Table 1. Full ripe seed phytohormones content at different storage periods with or without peel

\begin{tabular}{c|c|c|c|c|c|c}
\hline \multirow{2}{*}{ Treatment } & \multirow{2}{*}{ Determination index } & \multicolumn{6}{|c}{ Storage time (month) } \\
\cline { 3 - 7 } & & $\mathbf{0}$ & $\mathbf{1}$ & $\mathbf{2}$ & $\mathbf{3}$ & $\mathbf{4}$ \\
\hline With peel & \multirow{2}{*}{$\mathrm{GA}_{3}(\mathrm{ng} / \mathrm{g} . \mathrm{FW})$} & $9.25 \mathrm{~d}$ & $5.24 \mathrm{e}$ & $11.50 \mathrm{c}$ & $19.18 \mathrm{~b}$ & $39.95 \mathrm{a}$ \\
Without peel & & $15.61 \mathrm{~d}$ & $11.60 \mathrm{e}$ & $18.31 \mathrm{c}$ & $22.67 \mathrm{~b}$ & $52.52 \mathrm{a}$ \\
\hline With peel & \multirow{2}{*}{$\mathrm{ABA}(\mathrm{ng} / \mathrm{g} . \mathrm{FW})$} & $146.18 \mathrm{c}$ & $137.41 \mathrm{e}$ & $148.42 \mathrm{~b}$ & $169.33 \mathrm{a}$ & $138.01 \mathrm{~d}$ \\
Without peel & & $134.91 \mathrm{a}$ & $92.23 \mathrm{e}$ & $107.81 \mathrm{~b}$ & $97.03 \mathrm{~d}$ & $100.94 \mathrm{c}$ \\
\hline With peel & \multirow{2}{*}{$\mathrm{GA}_{3} / \mathrm{ABA}$} & $0.06 \mathrm{~d}$ & $0.04 \mathrm{e}$ & $0.08 \mathrm{c}$ & $0.11 \mathrm{~b}$ & $0.29 \mathrm{a}$ \\
Without peel & & $0.12 \mathrm{~d}$ & $0.13 \mathrm{~d}$ & $0.17 \mathrm{c}$ & $0.23 \mathrm{~b}$ & $0.51 \mathrm{a}$ \\
\hline
\end{tabular}

Different letters within a row indicate significant differences between the mean $(p<0.05)$

Table 2 showed that, wax ripe seed with or without peel, have significant differences $(\mathrm{p}<0.05)$ in endogenous $\mathrm{GA}_{3}, \mathrm{ABA}$ and $\mathrm{GA}_{3} / \mathrm{ABA}$ at different storage periods. GA3 content in wax ripe seed which was stored for three months was significantly lower in the seed without peel than seed with peel $(\mathrm{p}<0.05)$, the rest are significantly higher than wax ripe seed with peel ( $\mathrm{p}<0.05)$, with the storage time of $0 \mathrm{~m}$ (month), $1 \mathrm{~m}, 2 \mathrm{~m}$, $4 \mathrm{~m}$, and endogenous $\mathrm{GA}_{3}$ in wax ripe seed without peel than seed with peel, the increase by $67.7 \%, 15.5 \%, 80.1 \%$, and $59.9 \%$ was seen. Endogenous ABA in wax ripe seed with peel in each storage period are significantly higher than that without peel $(\mathrm{p}<0.05)$, with the extension of storage time, endogenous ABA in wax ripe seed with peel than seed without peel were increased by $55.6 \%, 152.8 \%, 165.9 \%, 270.9 \%$, and $72.9 \%$, respectively; this means that it contains a certain amount of ABA within the peel. The ratio of $\mathrm{GA}_{3} / \mathrm{ABA}$ in wax ripe seed without peel in each storage period are significantly higher than seed with peel $(\mathrm{p}<0.05)$. Moreover, with the extension of storage time, the ratio of $\mathrm{GA}_{3} / \mathrm{ABA}$ in full ripe seed without peel than seed with peel were increased by $161.0 \%, 191.9 \%, 378.8 \%, 209.9 \%, 176.3 \%$ (Table 2).

Table 2. Wax ripe seed phytohormones content of the different storage period with or without peel

\begin{tabular}{c|c|c|c|c|c|c}
\hline \multirow{2}{*}{ Treatment } & \multirow{2}{*}{ Determination index } & \multicolumn{6}{|c}{ Storage time (month) } \\
\cline { 3 - 7 } & & $\mathbf{0}$ & $\mathbf{1}$ & $\mathbf{2}$ & $\mathbf{3}$ & $\mathbf{4}$ \\
\hline With peel & \multirow{2}{*}{$\mathrm{GA}_{3}(\mathrm{ng} / \mathrm{g} . \mathrm{FW})$} & $19.79 \mathrm{c}$ & $20.10 \mathrm{c}$ & $16.45 \mathrm{~d}$ & $23.12 \mathrm{~b}$ & $37.09 \mathrm{a}$ \\
Without peel & $33.20 \mathrm{~b}$ & $23.20 \mathrm{~d}$ & $29.63 \mathrm{c}$ & $19.32 \mathrm{e}$ & $59.29 \mathrm{a}$ \\
\hline \multirow{2}{*}{ With peel } & \multirow{2}{*}{$\mathrm{ABA}(\mathrm{ng} / \mathrm{g} . \mathrm{FW})$} & $223.03 \mathrm{a}$ & $158.33 \mathrm{~d}$ & $169.16 \mathrm{c}$ & $202.80 \mathrm{~b}$ & $131.84 \mathrm{e}$ \\
Without peel & & $143.37 \mathrm{a}$ & $62.63 \mathrm{~d}$ & $63.62 \mathrm{c}$ & $54.67 \mathrm{e}$ & $76.27 \mathrm{~b}$ \\
\hline With peel & \multirow{2}{*}{$\mathrm{GA}_{3} / \mathrm{ABA}$} & $0.09 \mathrm{~d}$ & $0.13 \mathrm{~b}$ & $0.10 \mathrm{~cd}$ & $0.11 \mathrm{bc}$ & $0.28 \mathrm{a}$ \\
Without peel & & $0.23 \mathrm{~d}$ & $0.37 \mathrm{c}$ & $0.47 \mathrm{~b}$ & $0.35 \mathrm{c}$ & $0.78 \mathrm{a}$ \\
\hline
\end{tabular}

Different letters within a row indicate significant differences between the mean $(\mathrm{p}<0.05)$

Table 3 showed that, milky ripe seed with peel or without peel, the endogenous $\mathrm{GA}_{3}$, $\mathrm{ABA}$ and $\mathrm{GA}_{3} / \mathrm{ABA}$ at different storage periods have significant differences $(\mathrm{p}<0.05)$. Milky ripe seed without peel $\mathrm{GA}_{3}$ content in addition to storage for four month had no significant with seed with peel $(\mathrm{p}<0.05)$, the rest were significantly higher than seed 
with peel ( $\mathrm{p}<0.05$ ), with the storage time of $0 \mathrm{~m}$ (month), $1 \mathrm{~m}, 2 \mathrm{~m}, 3 \mathrm{~m}$, endogenous $\mathrm{GA}_{3}$ in milky ripe seed without peel than seed with peel were increased by $44.0 \%$, $37.7 \%, 76.9 \%$, and $25.7 \%$, respectively; the endogenous ABA in milky ripe seed with peel in each storage periods are significantly higher than seed without peel $(p<0.05)$, with the extension of storage time, endogenous ABA in milky ripe seed with peel than seed without peel were increased by $38.9 \%, 18.8,162.2,107.9,71.3 \%$, this means it contain a certain amount of ABA within the peel. Milky ripe seed without peel the ratio of $\mathrm{GA}_{3} / \mathrm{ABA}$ in addition to storage for 0 month had no significant difference with the seed with peel $(\mathrm{p}<0.05)$, the rest were significant $(\mathrm{p}<0.05)$; with the storage time of $2 \mathrm{~m}$ (month), $3 \mathrm{~m}, 4 \mathrm{~m}$, and the ratio of $\mathrm{GA}_{3} / \mathrm{ABA}$ in milky ripe seed without peel than seed with peel were increased by $48.2 \%, 65.4 \%$, and $73.6 \%$, respectively (Table 3 ).

Table 3. Milky ripe seed phytohormones content of the different storage period with or without peel

\begin{tabular}{c|c|c|c|c|c|c}
\hline \multirow{2}{*}{ Treatment } & \multirow{2}{*}{ Determination index } & \multicolumn{5}{|c}{ Storage time (month) } \\
\cline { 3 - 7 } & & $\mathbf{0}$ & $\mathbf{1}$ & $\mathbf{2}$ & $\mathbf{3}$ & $\mathbf{4}$ \\
\hline With peel & \multirow{2}{*}{$\mathrm{GA}_{3}$ (ng/g.FW) } & $8.62 \mathrm{e}$ & $10.53 \mathrm{~d}$ & $16.15 \mathrm{c}$ & $25.35 \mathrm{~b}$ & $55.07 \mathrm{a}$ \\
Without peel & & $5.99 \mathrm{e}$ & $7.65 \mathrm{~d}$ & $9.13 \mathrm{c}$ & $20.17 \mathrm{~b}$ & $55.82 \mathrm{a}$ \\
\hline With peel & \multirow{2}{*}{$\mathrm{ABA}(\mathrm{ng} / \mathrm{g} . \mathrm{FW})$} & $179.97 \mathrm{c}$ & $154.57 \mathrm{e}$ & $211.17 \mathrm{a}$ & $174.54 \mathrm{~d}$ & $189.59 \mathrm{~b}$ \\
Without peel & & $129.59 \mathrm{a}$ & $130.10 \mathrm{a}$ & $80.53 \mathrm{~d}$ & $83.94 \mathrm{c}$ & $110.70 \mathrm{~b}$ \\
\hline With peel & \multirow{2}{*}{$\mathrm{GA}_{3} / \mathrm{ABA}$} & $0.05 \mathrm{~d}$ & $0.07 \mathrm{c}$ & $0.08 \mathrm{c}$ & $0.15 \mathrm{~b}$ & $0.29 \mathrm{a}$ \\
Without peel & & $0.05 \mathrm{~d}$ & $0.06 \mathrm{~d}$ & $0.11 \mathrm{c}$ & $0.24 \mathrm{~b}$ & $0.50 \mathrm{a}$ \\
\hline
\end{tabular}

Different letters within a row indicate significant differences between the mean $(\mathrm{p}<0.05)$

Seed maturity has significant influence on germination potential, germination rate, germination index and $\mathrm{T}_{50}(\mathrm{~d})$. Uniformity was not significantly influenced by seed maturity. Germination potential, germination rate and germination index were significantly affected by $\mathrm{GA}_{3}$ processing time; however, this effect on uniformity and $\mathrm{T}_{50}(\mathrm{~d})$. Like, seed maturity, the interaction between seed maturity and $\mathrm{GA}_{3}$ processing time has significant effect on all experimental characteristics expect uniformity (Table 4).

Table 4. Analysis variance the effect of GA3 processing time on germination characteristics of seeds in different maturity

\begin{tabular}{c|c|c|c|c|c|c}
\hline S.O.V & d.f. & $\begin{array}{c}\text { Germination } \\
\text { potential (\%) }\end{array}$ & $\begin{array}{c}\text { Germination } \\
\text { rate (\%) }\end{array}$ & $\begin{array}{c}\text { Germination } \\
\text { index }\end{array}$ & Uniformity & $\begin{array}{c}\mathbf{T}_{\mathbf{5 0}} \\
(\mathbf{d})\end{array}$ \\
\hline Seed maturity (S) & 2 & $0.573^{* *}$ & $0.569^{* *}$ & $3296.65^{* *}$ & 0.002 & $1.622^{* *}$ \\
$\mathrm{GA}_{3}$ processing time (T) & 4 & $0.041^{* *}$ & $0.039^{* *}$ & $166.62^{* *}$ & $0.008^{\mathrm{ns}}$ & $0.222^{\mathrm{ns}}$ \\
$\mathrm{S} \times \mathrm{T}$ & 8 & $0.31^{* *}$ & $0.028^{* *}$ & $94.07^{*}$ & 0.004 & $0.122^{\mathrm{ns}}$ \\
Error & 28 & 0.008 & 0.007 & 29.173 & 0.005 & 0.094 \\
\hline
\end{tabular}

ns: non significant; *significant at 0.05 significance in F-tests; **significant at 0.001 significance in Ftests

The highest germination potential was related to full ripe seed and the lowest one was obtained by milky ripe seed, there was no significant difference between wax and 
full ripe seed, but both of them have significant differences with milky ripe seed. The maximum germination rate and germination index also achieved in full ripe seeds. No significant differences were found in these two experimental traits between milky and ripe seed, but both of them had significant differences with full ripe seed. There were no significant differences among milky ripe seed, wax ripe seed and full ripe seed. Wax ripe seed has obtained the highest $\mathrm{T}_{50}$, but its difference with full ripe seed was not significant. However, not only wax ripe seed, but also full ripe seed had significant difference with milky seed maturity. The maximum germination potential and germination rate was occurred in 120 and 60 min $\mathrm{GA}_{3}$ processing time, respectively. 120 min $\mathrm{GA}_{3}$ processing time had obtained the maximum germination index which just had significant differences with control treatment $(0 \mathrm{~min})$. There were no significant differences among treatments in uniformity index, furthermore, the maximum one was obtained by control treatment $(0 \mathrm{~min})$. On the one hand, the highest $\mathrm{T}_{50}$ was related to control treatment; on the other hand, the lowest one was obtained by 60,120 and $240 \mathrm{~min}$. Moreover, there were no significant differences among treatments. The results show that seeds immersed for $60 \mathrm{~m}$ by $\mathrm{GA}_{3}$ had best effect to promote germination to ripe seeds, and they inhibited germination when immersed for $240 \mathrm{~m}$. The maximum germination potential and germination rate was related to interaction between full ripe seed and $30 \mathrm{~min}$ of $\mathrm{GA}_{3}$ processing time, and the highest germination index was achieved in full ripe seed and 120 min $\mathrm{GA}_{3}$ processing time interaction. There were no significant differences among interaction traits in uniformity. Both, interaction between milky ripe seed and control treatment in processing time, interaction between milky ripe seed and $30 \mathrm{~min}$ of $\mathrm{GA}_{3}$ processing time had obtained the highest $\mathrm{T}_{50}$, which had significant differences with all other interaction (Table 5).

Table 5. Mean comparison for germination characteristics

\begin{tabular}{|c|c|c|c|c|c|}
\hline Treatment & $\begin{array}{l}\text { Germination } \\
\text { potential }(\%)\end{array}$ & $\begin{array}{c}\text { Germination rate } \\
(\%)\end{array}$ & $\begin{array}{c}\text { Germination } \\
\text { index }\end{array}$ & Uniformity & $\begin{array}{l}\mathbf{T}_{50} \\
\text { (d) }\end{array}$ \\
\hline Seed maturity $(\mathrm{S})$ & & & & & \\
\hline Milky ripe seed (S1) & $38.22 b$ & $35.47 b$ & $21.37 \mathrm{~b}$ & $0.9647 \mathrm{a}$ & $3.60 \mathrm{a}$ \\
\hline Wax ripe seed $(\mathrm{S} 2)$ & $49.78 \mathrm{a}$ & $34.67 \mathrm{~b}$ & $21.72 b$ & $0.9520 \mathrm{a}$ & $3.06 \mathrm{~b}$ \\
\hline Full ripe seed (S3) & $53.33 \mathrm{a}$ & $68.80 \mathrm{a}$ & $47.22 \mathrm{a}$ & $0.9767 \mathrm{a}$ & $3.00 \mathrm{~b}$ \\
\hline \multicolumn{6}{|l|}{$\begin{array}{c}\mathrm{GA}_{3} \text { processing time } \\
(\mathrm{m})(\mathrm{T})\end{array}$} \\
\hline $0(\mathrm{~T} 1)$ & $38 \mathrm{c}$ & $45 c$ & $23.62 b$ & $1.00 \mathrm{a}$ & $3.33 \mathrm{ab}$ \\
\hline $30(\mathrm{~T} 2)$ & $49 a b$ & $52 \mathrm{c}$ & $29.65 a$ & $0.95 \mathrm{a}$ & $3.44 \mathrm{a}$ \\
\hline $60(\mathrm{~T} 3)$ & $53 \mathrm{a}$ & $53 \mathrm{a}$ & $33.58 \mathrm{a}$ & $0.99 \mathrm{a}$ & $3.11 \mathrm{~b}$ \\
\hline $120(\mathrm{~T} 4)$ & $54 \mathrm{a}$ & $43 d$ & $34.45 \mathrm{a}$ & $0.94 \mathrm{a}$ & $3.11 \mathrm{~b}$ \\
\hline $240(\mathrm{~T} 5)$ & $44 \mathrm{bc}$ & $28 b$ & $29.20 \mathrm{a}$ & $0.93 \mathrm{a}$ & $3.11 \mathrm{~b}$ \\
\hline \multicolumn{6}{|l|}{$\begin{array}{c}\text { Seed maturity } \times \mathrm{GA}_{3} \\
\text { processing time } \\
(\mathrm{S} \times \mathrm{T})\end{array}$} \\
\hline $\mathrm{S} 1 \mathrm{~T} 1$ & $24 \mathrm{~h}$ & $22 \mathrm{~h}$ & $12.53 \mathrm{e}$ & $1.00 \mathrm{a}$ & $4.00 \mathrm{a}$ \\
\hline $\mathrm{S} 1 \mathrm{~T} 2$ & $29 \mathrm{~h}$ & $24 \mathrm{gh}$ & $15.27 \mathrm{de}$ & $1.00 \mathrm{a}$ & $4.00 \mathrm{a}$ \\
\hline S1T3 & 49defg & 46def & $28.31 \mathrm{c}$ & $0.97 \mathrm{a}$ & $3.33 b$ \\
\hline S1T4 & $52 \mathrm{def}$ & $50 \mathrm{cde}$ & $29.25 c$ & $0.96 \mathrm{a}$ & $3.33 b$ \\
\hline S1T5 & $37 \mathrm{fgh}$ & $33 \mathrm{fgh}$ & $21.49 \mathrm{cde}$ & $0.89 \mathrm{a}$ & $3.33 b$ \\
\hline S2T1 & $21 \mathrm{~h}$ & $21 \mathrm{~h}$ & $13.33 \mathrm{e}$ & $1.00 \mathrm{a}$ & $3.00 \mathrm{~b}$ \\
\hline
\end{tabular}




\begin{tabular}{l|c|c|c|c|c}
\hline S2T2 & $36 f g h$ & $34 f g h$ & $21.17 \mathrm{cde}$ & $0.93 \mathrm{a}$ & $3.33 \mathrm{~b}$ \\
S2T3 & $46 \mathrm{efg}$ & $45 \mathrm{def}$ & $28.44 \mathrm{c}$ & $1.00 \mathrm{a}$ & $3.00 \mathrm{~b}$ \\
S2T4 & $33 \mathrm{gh}$ & $33 \mathrm{fgh}$ & $20.64 \mathrm{cde}$ & $0.91 \mathrm{a}$ & $3.00 \mathrm{~b}$ \\
S2T5 & $37 \mathrm{fgh}$ & $38 \mathrm{efg}$ & $25.00 \mathrm{~cd}$ & $0.90 \mathrm{a}$ & $3.00 \mathrm{~b}$ \\
S3T1 & $69 \mathrm{abc}$ & $68 \mathrm{ab}$ & $45.00 \mathrm{ab}$ & $1.00 \mathrm{a}$ & $3.00 \mathrm{~b}$ \\
S3T2 & $84 \mathrm{a}$ & $78 \mathrm{a}$ & $52.52 \mathrm{a}$ & $0.92 \mathrm{a}$ & $3.00 \mathrm{~b}$ \\
S3T3 & $64 \mathrm{bcd}$ & $64 \mathrm{abc}$ & $44.00 \mathrm{ab}$ & $1.00 \mathrm{a}$ & $3.00 \mathrm{~b}$ \\
S3T4 & $77 \mathrm{ab}$ & $76 \mathrm{a}$ & $53.46 \mathrm{a}$ & $0.96 \mathrm{a}$ & $3.00 \mathrm{~b}$ \\
S3T5 & $57 \mathrm{cde}$ & $57 \mathrm{bcd}$ & $41.11 \mathrm{~b}$ & $1.00 \mathrm{a}$ & $3.00 \mathrm{~b}$ \\
\hline
\end{tabular}

Means with common letters within each column do not differ significantly. The effect of seed maturity, $\mathrm{GA}_{3}$ processing time, and their interaction were evaluated. The treatments for seed manturity were milky ripe seed (S1), wax ripe seed (S2), and full ripe seed (S3). The treatments for $\mathrm{GA}_{3}$ processing time were0 (T1), 30 (T2), 60 (T3), 120 (T4), and 240 m (T5)

Germination potential has positive and significant correlation with germination rate and germination index, which means that with increase of germination potential, germination rate increase significantly. However, germination potential has negative and significant correlation with $\mathrm{T}_{50}$ and non-significant positive correlation with uniformity. The positive significant correlation was found between germination rate and germination index. $\mathrm{T}_{50}$ also had negative and significant correlation with both germination rate and germination index. Furthermore, the correlation between uniformity and $\mathrm{T}_{50}$ was positive, but it was not significant (Table 6). $\mathrm{GA}_{3}$ concentration had significant influence on germination potential, germination rate and germination index, but uniformity and $\mathrm{T}_{50}$ were not affected by it (Table 7).

Table 6. Simple correlation among experimental characteristics in different seed maturity and GA3 processing time

\begin{tabular}{c|c|c|c|c|c}
\hline Traits & $\begin{array}{c}\text { Germination } \\
\text { potential }\end{array}$ & $\begin{array}{c}\text { Germination } \\
\text { rate }\end{array}$ & $\begin{array}{c}\text { Germination } \\
\text { index }\end{array}$ & Uniformity & T50 $_{50}$ \\
\hline Germination potential & 1 & & & & \\
Germination rate & $0.988^{* *}$ & 1 & 1 & & \\
Germination index & $0.978^{* *}$ & $0.987^{* *}$ & $0.063^{\mathrm{ns}}$ & 1 & 1 \\
Uniformity & $0.009^{\mathrm{ns}}$ & $0.060^{\mathrm{ns}}$ & $-0.510^{* *}$ & $0.004^{\mathrm{ns}}$ & 1 \\
$\mathrm{~T}_{50}$ & $-0.439^{* *}$ & $-0.498^{* *}$ & & & \\
\hline
\end{tabular}

ns: non significant; *significant at 0.05 significance in F-tests; **significant at 0.001 significance in Ftests

Table 7. Analysis of variance for the influence of different GA3 concentrations on wax ripe seed germination

\begin{tabular}{c|c|c|c|c|c|c}
\hline S.O.V & d.f. & $\begin{array}{c}\text { Germination } \\
\text { potential }\end{array}$ & $\begin{array}{c}\text { Germination } \\
\text { rate }\end{array}$ & $\begin{array}{c}\text { Germination } \\
\text { index }\end{array}$ & Uniformity & T50 $_{\mathbf{5 0}}$ \\
\hline Replication & 2 & 0.006 & 0.006 & 16.98 & $0.012^{\mathrm{ns}}$ & 0.056 \\
$\mathrm{GA}_{3}$ concentrations & 5 & $0.055^{* *}$ & $0.088^{* *}$ & $195.77^{* *}$ & $0.022^{\mathrm{ns}}$ & $0.489^{\mathrm{ns}}$ \\
Error & 10 & 0.008 & 0.007 & 24.89 & 0.008 & 0.182 \\
\hline
\end{tabular}

ns, non significant; *significant at 0.05 significance in F-tests; **significant at 0.001 significance in Ftests 
The highest germination potential and germination rate was related to $100 \mathrm{mg} \mathrm{L}^{-1}$ $\mathrm{GA}_{3}$ concentration, which had significant differences with all treatments, except $200 \mathrm{mg}$ $\mathrm{L}^{-1}$ in both experimental traits. The highest and the lowest germination rate were achieved in $100 \mathrm{mg} \mathrm{L}^{-1}$ and control treatment $\left(0 \mathrm{mg} \mathrm{L}^{-1}\right) \mathrm{GA}_{3}$ concentration, which had significant difference with each other. $100 \mathrm{GA}_{3}$ concentration had obtained the maximum germination index, which had significant differences with $0 \mathrm{mg} \mathrm{L}^{-1}$ and $12.5 \mathrm{mg} \mathrm{L}^{-1}$. There were no significant differences among treatments in uniformity. The highest $\mathrm{T}_{50}$ was related to $50 \mathrm{mg} \mathrm{L}^{-1}$ and $100 \mathrm{mg} \mathrm{L}^{-1}$, respectively. Like uniformity, no significant difference was found among treatments (Table 8).

Table 8. Mean comparison for experimental characteristics of wax ripe seed germination in different $G A 3$ concentration

\begin{tabular}{c|c|c|c|c|c}
\hline Treatment & $\begin{array}{c}\text { Germination } \\
\text { potential (\%) }\end{array}$ & $\begin{array}{c}\text { Germination } \\
\text { rate (\%) }\end{array}$ & $\begin{array}{c}\text { Germination } \\
\text { index }\end{array}$ & Uniformity & $\begin{array}{c}\mathbf{T}_{\mathbf{5 0}} \\
\mathbf{( d )}\end{array}$ \\
\hline $\mathrm{GA}_{3}$ concentration $\left(\mathrm{mg} \mathrm{L}^{-1}\right)$ & & & & & \\
0 & $21.3 \mathrm{~d}$ & $21.3 \mathrm{c}$ & $13.33 \mathrm{c}$ & $1.00 \mathrm{a}$ & $3.00 \mathrm{a}$ \\
12.5 & $26.7 \mathrm{~cd}$ & $26.7 \mathrm{c}$ & $15.99 \mathrm{bc}$ & $1.00 \mathrm{a}$ & $3.33 \mathrm{ab}$ \\
25 & $37.3 \mathrm{bcd}$ & $49.3 \mathrm{~b}$ & $25.75 \mathrm{a}$ & $0.82 \mathrm{a}$ & $3.33 \mathrm{ab}$ \\
50 & $41.3 \mathrm{abc}$ & $49.3 \mathrm{~b}$ & $25.01 \mathrm{ab}$ & $0.85 \mathrm{a}$ & $4.00 \mathrm{a}$ \\
100 & $57.3 \mathrm{a}$ & $66.7 \mathrm{a}$ & $33.98 \mathrm{a}$ & $0.84 \mathrm{a}$ & $4.00 \mathrm{a}$ \\
200 & $49.3 \mathrm{ab}$ & $53.3 \mathrm{ab}$ & $30.09 \mathrm{a}$ & $0.82 \mathrm{a}$ & $3.66 \mathrm{ab}$ \\
\hline
\end{tabular}

Means with common letters within each column do not differ significantly

\section{Influence of different maturity seed germination by dealing with GA3}

The results showed that, after manual peel out seed, the immersed with $\mathrm{GA}_{3}$, seeds in different maturity had significantly improved germination rate, germination energy and germination index, which had significant difference with other treatments. Manual removal treatment $(\mathrm{B} 2)$ and $\mathrm{GA}_{3}$ treatment (B3) had significant difference with $\mathrm{B} 1$ in germination rate. Milky ripe seeds had significant differences in germination potential by dealing with $\mathrm{GA}_{3}$; seeds treated by $\mathrm{B} 4$ were significantly higher than other treatments in germination rate, there was no significant difference between B2 and B3, but also it was significantly higher than B1; seeds treated by B4 was significantly higher than other treatments in germination index, when others have no significant difference; $\mathrm{T}_{50}$ of $\mathrm{B} 4$ and $\mathrm{B} 3$ is shortened one day than B2 and B1. B4 had no significant difference with $\mathrm{B} 3$ in the germination potential of wax ripe seed, but it was significantly higher than B2 and B1; furthermore, there was no significant difference between B3 and B2, but B3 was significantly higher than B1. There was no significant difference between $\mathrm{B} 2$ and $\mathrm{B} 1$; seed treated by $\mathrm{B} 4$ was significantly higher than other treatments in germination rate, there was no significant difference between B2 and B3, but they were significantly higher than B1. Seed treated by B4 was significantly higher than other treatments in germination rate, furthermore, B2 was significantly higher than B3 and B1 in germination index, and there was no significant difference between $\mathrm{B} 3$ and $\mathrm{B} 1 \mathrm{~T}_{50}$ of B4 and B3 was shortened one day than B2 and B1. Full ripe seed had significant difference in germination potential. Full ripe seed had significant difference in germination rate, there was no significant difference between B4 and B1, but all of them were significantly higher than other treatments; $\mathrm{T}_{50}$ of $\mathrm{B} 4$ and $\mathrm{B} 3$ is shortened one day than B2 and B1 (Table 9). 
Table 9. Influence of different maturity seed germination by dealing with GA3

\begin{tabular}{c|c|c|c|c}
\hline \multirow{2}{*}{ Provenances } & \multicolumn{4}{|c}{ treatments } \\
\cline { 2 - 5 } & B1 & B2 & B3 & B4 \\
\hline Milky ripe & & & & \\
Germination rate $(\%)$ & $0.0 \mathrm{~d}$ & $2.5 \mathrm{c}$ & $3.2 \mathrm{~b}$ & $3.7 \mathrm{a}$ \\
Germination potential (\%) & $40.7 \mathrm{c}$ & $56.0 \mathrm{~b}$ & $58.7 \mathrm{~b}$ & $65.3 \mathrm{a}$ \\
Germination index & $13.3 \mathrm{~b}$ & $13.4 \mathrm{~b}$ & $12.9 \mathrm{~b}$ & $22.1 \mathrm{a}$ \\
$\mathrm{T}_{50}(\mathrm{~d})$ & 8 & 8 & 7 & 7 \\
Geminating & 0.9 & 1.0 & 1.0 & 0.8 \\
\hline Wax ripe & & & & \\
Germination rate $(\%)$ & $2.7 \mathrm{c}$ & $3.0 \mathrm{bc}$ & $3.5 \mathrm{ab}$ & $4.0 \mathrm{a}$ \\
Germination potential (\%) & $42.7 \mathrm{c}$ & $65.3 \mathrm{~b}$ & $67.3 \mathrm{~b}$ & $80.0 \mathrm{a}$ \\
Germination index & $11.5 \mathrm{c}$ & $16.8 \mathrm{~b}$ & $13.2 \mathrm{c}$ & $22.8 \mathrm{a}$ \\
T50 $(\mathrm{d})$ & 8 & 8 & 7 & 7 \\
Geminating & 0.8 & 0.9 & 0.9 & 0.8 \\
\hline Full ripe & & & & \\
Germination rate $(\%)$ & $6.7 \mathrm{~d}$ & $8.3 \mathrm{c}$ & $15.3 \mathrm{~b}$ & $22.7 \mathrm{a}$ \\
Germination potential $(\%)$ & $75.7 \mathrm{~d}$ & $77.3 \mathrm{c}$ & $79.3 \mathrm{~b}$ & $92.0 \mathrm{a}$ \\
Germination index & $28.1 \mathrm{a}$ & $20.6 \mathrm{~b}$ & $16.1 \mathrm{c}$ & $29.6 \mathrm{a}$ \\
$T_{50}(\mathrm{~d})$ & 7 & 7 & 6 & 6 \\
\hline
\end{tabular}

Different letters within a row indicate significant differences between the mean $(p<0.05)$

\section{Influence of different maturity seed germination under low temperature and room temperature storage conditions by dealing with GA3}

The results showed that using $\mathrm{GA}_{3}$ treatment to harvest and storage one month cream ripe seed at room temperature, the germination rate were higher than comparison results, the difference reached significant level $(\mathrm{p}<0.05)$, increasing 8 and 5.1 percentage points; using $\mathrm{GA}_{3}$ treatment at room temperature to storage for two months, three months and four months, seed germination rate compared to the comparison was not significant. Storage at room temperature for three and four months, seed germination rate was lower than the comparison, reduced by 2 and 3 percentage points. Germination rate of the new harvest, cold storage for one and two months milk ripe seed treated by $\mathrm{GA}_{3}$, was higher than the comparison, the difference reached significant level ( $\mathrm{p}<0.05$ ), increasing 8, 6.9 and 5.5 percentage points, respectively; germination rate of cold storage two and three months milky ripe seed treated by GA 3 was lower than the comparison for $4 \%$, the difference was not significant (Table 10).

Table 10. Influence of milky ripe seed germination under room temperature and $0^{\circ} \mathrm{C}$ storage conditions by dealing with GA3

\begin{tabular}{c|c|c|c|c|c}
\hline \multirow{2}{*}{ Treatment } & \multicolumn{5}{c}{ Germination rate (\%) } \\
\cline { 2 - 6 } & 0 month & 1 month & 2 month & 3 month & 4 month \\
\hline Room temperature and no GA 3 & $11 \mathrm{e}$ & $35.1 \mathrm{~d}$ & $46.7 \mathrm{c}$ & $55 \mathrm{~b}$ & $73 \mathrm{a}$ \\
Room temperature and $\mathrm{GA}_{3}$ & $19 \mathrm{~d}$ & $40.2 \mathrm{c}$ & $50.3 \mathrm{~b}$ & $53 \mathrm{~b}$ & $70 \mathrm{a}$ \\
$0{ }^{\circ} \mathrm{C}$ and no GA 3 & $11 \mathrm{e}$ & $30.4 \mathrm{~d}$ & $40.2 \mathrm{c}$ & $50 \mathrm{~b}$ & $69 \mathrm{a}$ \\
$0^{\circ} \mathrm{C}$ and $\mathrm{GA}_{3}$ & $19 \mathrm{e}$ & $37.3 \mathrm{~d}$ & $45.7 \mathrm{c}$ & $51 \mathrm{~b}$ & $65 \mathrm{a}$ \\
\hline
\end{tabular}

Different letters within a row indicate significant differences between the mean $(\mathrm{p}<0.05)$ 
Using $\mathrm{GA}_{3}$ treatment to newly harvested and stored one month wax ripe seeds at room temperature, the germination rate was higher than comparison results, the difference reached significant level $(\mathrm{p}<0.05)$, increasing by 10 and 5.5 percent; Using $\mathrm{GA}_{3}$ treatment at room temperature and stored for two, three and four months, seed germination rate compared to the comparison was not significant, storage at room temperature for four months, seed germination rate was lower than the comparison, reducing it by $3.5 \%$. Germination rate of the new harvest, cold storage for one and two months wax ripe seeds treated with $\mathrm{GA}_{3}$ was higher than the comparison, the difference reached significant level, increasing by $10,7.1$ and $9.6 \%$. Germination rate of cold storage two and three months wax ripe seeds treated by $\mathrm{GA}_{3}$ was lower than the comparison by $2 \%$, the difference was not significant (Table 11).

Table 11. Influence of full ripe seed germination under room temperature and $0^{\circ} \mathrm{C}$ storage conditions by dealing with GA3

\begin{tabular}{c|c|c|c|c|c}
\hline \multirow{2}{*}{ Treatment } & \multicolumn{5}{c}{ Germination rate (\%) } \\
\cline { 2 - 6 } & 0 month & 1 month & 2 month & 3 month & 4 month \\
\hline Room temperature and no GA3 & $26.3 \mathrm{~d}$ & $50.8 \mathrm{c}$ & $82.2 \mathrm{~b}$ & $92.1 \mathrm{a}$ & $90.3 \mathrm{a}$ \\
Room temperature and GA3 & $43.2 \mathrm{c}$ & $78.5 \mathrm{~b}$ & $90.5 \mathrm{a}$ & $90.2 \mathrm{a}$ & $91.6 \mathrm{a}$ \\
$0{ }^{\circ} \mathrm{C}$ and no GA3 & $26.3 \mathrm{e}$ & $45.6 \mathrm{~d}$ & $72 \mathrm{c}$ & $82 \mathrm{~b}$ & $88 \mathrm{a}$ \\
$0^{\circ} \mathrm{C}$ and GA3 & $43.2 \mathrm{~d}$ & $65.6 \mathrm{c}$ & $83 \mathrm{~b}$ & $80 \mathrm{ab}$ & $85 \mathrm{a}$ \\
\hline
\end{tabular}

Different letters within a row indicate significant differences between the mean $(p<0.05)$

Using $\mathrm{GA}_{3}$ treatment to harvest and storage one and two month fully mature seeds at room temperature, the germination rate was both higher than comparison results, the difference reached extremely significant level $(p<0.01)$, increasing 16.9, 27.7 and $8.3 \%$; using $\mathrm{GA}_{3}$ treatment at room temperature to storage for three and four months, seed germination rate compared to the comparison was not significant $(p>0.05)$, storage at room temperature for three months, seed germination rate was lower than the comparison reducing it by 1.9 percentage points; germination rate of the new harvest, cold storage a month and two months fully mature seeds treated by $\mathrm{GA}_{3}$ had higher than the comparison, the difference reached significant level $(p<0.05)$, increasing by 16.9, 20 and 9\%, respectively; germination rate of cold storage three and four months fully mature seeds treated by $\mathrm{GA}_{3}$ was lower than the comparison by $2 \%$ and $3 \%$, according to storage period for the sequence, the difference was not significant (Table 12).

Table 12. Influence of wax ripe seed germination under room temperature and $0^{\circ} \mathrm{C}$ storage conditions by dealing with $\mathrm{GA}_{3}$

\begin{tabular}{c|c|c|c|c|c}
\hline \multirow{2}{*}{ Treatment } & \multicolumn{5}{c}{ Germination rate $(\%)$} \\
\cline { 2 - 6 } & 0 month & 1 month & 2 month & 3 month & 4 month \\
\hline Room temperature and no GA 3 & $14.4 \mathrm{e}$ & $50.3 \mathrm{~d}$ & $69.3 \mathrm{c}$ & $80 \mathrm{~b}$ & $85.5 \mathrm{a}$ \\
Room temperature and $\mathrm{GA}_{3}$ & $24.4 \mathrm{~d}$ & $55.8 \mathrm{c}$ & $73.3 \mathrm{~b}$ & $81 \mathrm{a}$ & $82 \mathrm{a}$ \\
$0{ }^{\circ} \mathrm{C}$ and no GA & $14.4 \mathrm{e}$ & $45 \mathrm{~d}$ & $60.7 \mathrm{c}$ & $73 \mathrm{~b}$ & $82 \mathrm{a}$ \\
$0^{\circ} \mathrm{C}$ and $\mathrm{GA}_{3}$ & $24.4 \mathrm{e}$ & $52.1 \mathrm{~d}$ & $70.3 \mathrm{c}$ & $74 \mathrm{~b}$ & $80 \mathrm{a}$ \\
\hline
\end{tabular}

Different letters within a row indicate significant differences between the mean $(p<0.05)$ 
The results of this experiment showed that the $\mathrm{GA}_{3}$ treatment promote seed storage at room temperature or low temperature seed germination, especially for two months, but not for three or more months or even inhibition.

\section{GA3 and ABA interaction effects on seed germination}

The test results showed the significant differences, in the germination rate of each treatment compared with CK, D5, D6, D7 $(p<0.01)$; the D8 germination rate was significantly higher than that of D4, D3, D2, D1, $(p<0.05)$. D1 and D2 were the most important treatment which inhibited seed germination compare to other treatments, seed germination in D3 and D4 were $36.0 \%$ and $24.0 \%$, respectively; under the same concentration of $\mathrm{ABA}$, the seed germination rate of $\mathrm{ABA}$ and $\mathrm{GA}_{3}$ interaction treatment was higher than ABA treatment, but it was still lower than CK levels. These results suggest that $\mathrm{ABA}$ inhibits seed germination, and inhibition increased with the increase trend of $\mathrm{ABA}$ concentration; furthermore $\mathrm{GA}_{3}$ can alleviate the inhibitory effect of $\mathrm{ABA}$ on seed germination and alleviating margin of $\mathrm{D} 1, \mathrm{D} 2$ with $\mathrm{GA}_{3}$ is larger than the D3, D4 (Fig. 1).

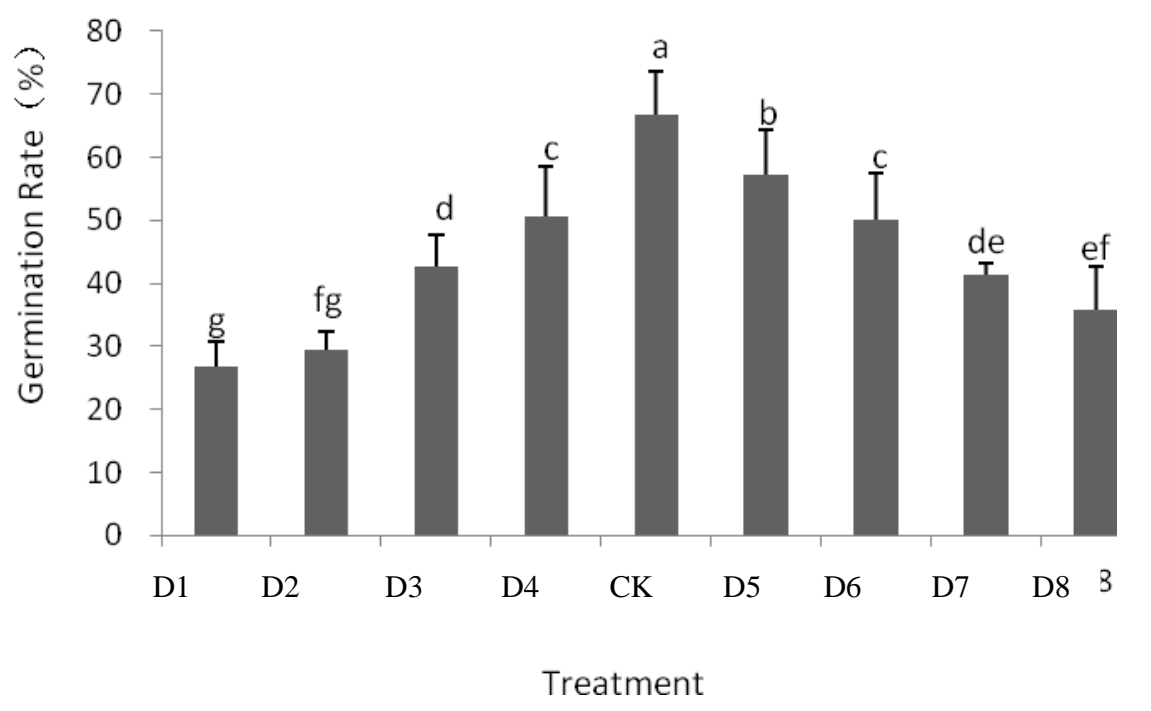

Figure 1. $\mathrm{GA}_{3}$ and $A B A$ interaction effects on seed germination

The results of this experiment showed that the endogenous $\mathrm{GA}_{3}$ content of each maturity degree oat seed increased with the storage period, while endogenous ABA content decreased with storage time to extend. Different maturity seed $\mathrm{GA}_{3} / \mathrm{ABA}$ ratio increase with the storage time, and this result is the same for maturity germination rate. Furthermore, $\mathrm{GA}_{3}$ content of seed without peel were higher than those with peel at each storage time, while ABA content showed the opposite. Thus, the peel may contain more ABA and conducive to seed dormancy. This was in agree with the observed germination of wild oat with positive relationship between $\mathrm{ABA} / \mathrm{GA}_{3}$ ratio and seed germination, it further strongly affected the dormancy rate (Yu et al., 2016; Esashi, 2017). Zeng and Zhao (2001) indicated that the red string seed showed during seed development, the content of endogenous $\mathrm{GA}_{3}$ showed a decreasing trend, that $\mathrm{GA}_{3}$ content in dry seeds in room temperature and low temperature during storage have 
shown pre gradually reduce, the latter has an upturn, and the content of endogenous $\mathrm{GA}_{3}$ and no significant correlation with the seed germination rate. Seed germination rate significantly increased with storage time extended, the role of $\mathrm{GA}_{3}$ to enhance the seed germination rate weakened. This is similar to the results of Zeng and Zhao (2001) that related to $\mathrm{GA}_{3}$, a role on a red string seed germination. This experiment showed that when seeds are treated with different concentrations of exogenous ABA, seed germination rate decreased with the increase of ABA concentration, even when at the same time there is application of $\mathrm{GA}_{3}$, the germination rate of seed was certain upward, but still lower than in $\mathrm{CK}$. So ABA inhibited seed germination, but its inhibitory effect in a certain extent can be remission by $\mathrm{GA}_{3}$. Wang et al. (2004) also reported the influence of $\mathrm{ABA}$ on the inhibition of rice seed germination results.

\section{Conclusions}

Seeds without peel had lower endogenous $\mathrm{ABA}$ content and the ratio of $\mathrm{ABA} / \mathrm{GA}_{3}$ than seeds with peel. The best $\mathrm{GA}_{3}$ treatment time for milky ripe, wax ripe, full ripe seed were $60 \mathrm{~min}(\mathrm{~m})$ or $120 \mathrm{~m}, 60 \mathrm{~m}$, and $30 \mathrm{~m}$, respectively. Seed germination rate, germination potential and germination index were all first increased and then decreased with increasing GA3 concentrations. The best treatment concentration of $\mathrm{GA}_{3}$ was $100 \mathrm{mg} \mathrm{L}^{-1}$, the turning point was $200 \mathrm{mg} \mathrm{L}^{-1}$. The dormancy rate of low temperature storage seeds were higher than those stored in room temperature at each storage time, and both were decreased with the storage time. New seeds or stored for 1-2 months, showed significantly enhanced germination rate by exogenous $\mathrm{GA}_{3}$. GA3 treatment had no effect on germination rate for seeds that had been stored for over 3 months. ABA inhibits the germination rate, which decreases with the increasing concentration of ABA. The most inhibitive effect, which leaded to a seed germination reduction by $37.7 \%$ and $4.0 \%$, appeared when the concentration of ABA was 500 and $1000 \mathrm{mg} \mathrm{L}^{-1}$. $\mathrm{GA}_{3}$ could abate the effect which $\mathrm{ABA}$ inhibited seed germination.

Acknowledgements. We are grateful to the study grants from the earmarked fund for China Agriculture Research System (CARS-08-B-1). Thanks to the guidance of Laichun Guo and Chunlong Wang in the experiment, and thanks the workers in Baicheng Academy of Agricultural Sciences for their skilled technical assistant.

\section{REFERENCES}

[1] Beck, E., Ziegler, P. (1989): Biosynthesis and degradation of starch in higher plants. Ann Rev Plant Physiol. 40: 95-117.

[2] Cheng, L., Lu, Q., Wu, B., Yin, C., Bao, Y., Gong, L. (2018): Estimation of the costs of desertification in China: a critical review. - Land Degradation \& Development 29(4): 975-983.

[3] Damaris, R. N., Lin, Z., Yang, P., He, D. (2019): The Rice Alpha-Amylase, Conserved Regulator of Seed Maturation and Germination. - International Journal of Molecular Sciences 20(2): 450 .

[4] Esashi, Y. (2017): Ethylene and Seed Germination. - In: Mattoo, A. K. (ed.) The Plant Hormone Ethylene. CRC Press, Boca Raton, FL, pp. 133-157.

[5] Finch-Savage, W. E., Leubner-Metzger, G. (2006): Seed dormancy and the control of germination. - New Phytologist 171(3): 501-523. 
[6] Islam, M. R., Shahidul, A. M., Eneji, A. E., Ren, C. Z., Song, W. J., Hu, Y. G. (2011): Evaluation of water-saving superabsorbent polymer for forage oat (Avena sativa L.) production in arid regions of northern China. - Journal of Food, Agriculture and Environment 9(2): 514-518.

[7] Khan, T. A., Nadeem, F., Gao, Y., Yang, Y., Wang, X., Zeng, Z., Hu, Y. (2019): A larger root system in oat (Avena nuda L.) is coupled with enhanced biomass accumulation and hormonal alterations under low nitrogen. - Applied Ecology and Environmental Research 17(2): 4631-4653.

[8] Li, M., Hu, Y. G., Zeng, Z. H., Ren, C. Z., Mao, N., Song, W. J., Jia, P. F. (2009): Wind tunnel experiment on anti-wind erosion capacity of four crop stubbles in Horqin sandy land. - Chinese Agricultural Science Bulletin 11: 254-258 (in Chinese).

[9] Lin, Y. C., Zeng, Z. H., Ren, C. Z., Guo, L. C, Wang, C. L., Hlatshwayo, P., Hu, Y. G. (2012): Effects of different soil moisture regimes on gas exchange in response to light, growth and biomass in naked oat (Avena nuda L.) - Journal of Food, Agriculture and Environment 10(3-4): 1473-1478.

[10] Liu, X., Hu, P., Huang, M., Tang, Y., Li, Y., Li, L., Hou, X. (2016): The NF-YC-RGL2 module integrates GA and ABA signalling to regulate seed germination in Arabidopsis. Nature Communications 7: 12768 .

[11] Lou, Y. L., Feng, Z. H. (1995): Lixia River region of Jiangsu Province of wheat following rice field oats the summering law research. - Jiangsu Journal of Agricultural Sciences 11: 25-29 (in Chinese).

[12] Mukhtar, F. B., Singh, B. B. (2006): Influence of photoperiod and gibberellic acid (GA3) on the growth and flowering of cowpea (Vigna unguiculata (L.) Walp). - Journal of Food, Agriculture and Environment 4(2): 201-203.

[13] Ozkaya, O., Dundar, O., Kuden, A. (2006): Effect of preharvest gibberellic acid treatments on postharvest quality of sweet cherry. - Journal of Food, Agriculture and Environment 4(1): 189-191.

[14] Qian, X., Zang, H., Xu, H., Hu, Y., Ren, C., Guo, L., ... Zeng, Z. (2018): Relay strip intercropping of oat with maize, sunflower and mung bean in semi-arid regions of Northeast China: Yield advantages and economic benefits. - Field Crops Research 223: 33-40.

[15] Rabiei, E., Khodambashi, M., Pirbalouti, G. (2012): The study of the drought tolerance indices of oat (Avena sativa L.). - Journal of Food, Agriculture and Environment 10(2): 646-648.

[16] Ren, C. Z., Ma, B. L., Burrows, V., Zhou, J., Hu, Y. G., Guo, L., Wei, L., Sha, L., Deng, L. (2007): Evaluation of early mature naked oat varieties as a summer-seeded crop in dryland northern climate regions. - Field Crops Research 103: 248-254.

[17] Wang, X., Tao, L. X., Huang, X. L. (2004): Physiological mechanisms of exogenous ABA inhibition of germination of rice seeds. - Acta Agronomica Sinica 30: 1250-1253 (in Chinese).

[18] Wilkinson, S., Davies, W. J. (2010): Ozone ABA and ethylene: new insights from cell to plant to community. - Plant Cell Environ 33: 510-525.

[19] Yu, Y., Zhen, S., Wang, S., Wang, Y., Cao, H., Zhang, Y., ... Yan, Y. (2016): Comparative transcriptome analysis of wheat embryo and endosperm responses to ABA and $\mathrm{H} 2 \mathrm{O} 2$ stresses during seed germination. - BMC Genomics 17(1): 97.

[20] Zang, H., Qian, X., Wen, Y., Hu, Y., Ren, C., Zeng, Z., ... Wang, C. (2018): Contrasting carbon and nitrogen rhizodeposition patterns of soya bean (Glycine max L.) and oat (Avena nuda L.). - European Journal of Soil Science 69(4): 625-633.

[21] Zeng, L., Zhao, L. J. (2001): Effects of GA3 and ABA on seed development and germination of Salvia splendens. - Journal of Shanghai Jiaotong University (Agricultural Science) 4: 276-279 (in Chinese).

[22] Zhang, Q., Van Wijk, R., Shahbaz, M., Roels, W., Schooten, B. V., Vermeer, J. E., Laha, D. (2017): Arabidopsis phospholipase C3 is involved in lateral root initiation and ABA 
responses in seed germination and stomatal closure. - Plant and Cell Physiology 59(3): 469-486.

\section{APPENDIX}

Table A1. The summary of all experiments and treatments evaluated in present study

\begin{tabular}{|c|c|}
\hline Experiment & Treatment \\
\hline $\mathrm{a}$ & $\begin{array}{l}\text { Factor } 1(\text { Seed maturity): } \mathrm{S} 1=\text { milky ripe, } \mathrm{S} 2=\text { wax ripe, and } \mathrm{S} 3=\text { full ripe } \\
\text { Factor } 2\left(\mathrm{GA}_{3} \text { treat time }\right): \mathrm{T} 1=0, \mathrm{~T} 2=30, \mathrm{~T} 3=60, \mathrm{~T} 4=120, \text { and } \mathrm{T} 5=240 \mathrm{~min}\end{array}$ \\
\hline $\mathrm{b}$ & $\begin{array}{l}\text { Factor } 1\left(\mathrm{GA}_{3} \text { concentration }\right): \mathrm{A} 1=0, \mathrm{~A} 2=12.5, \mathrm{~A} 3=25, \mathrm{~A} 4=50, \mathrm{~A} 5=100 \text {, and } \\
\qquad \mathrm{A} 6=200 \mathrm{mg} \mathrm{L}^{-1}\end{array}$ \\
\hline $\mathrm{c}$ & $\begin{array}{l}\text { B1 = seeds with peel, B2 = seeds without peel, B3 = seeds with peel, soaked in GA3 for } \\
\qquad 2 \mathrm{~h} \text {, and B4 = seeds without peel, soaked in GA3 for } 2 \mathrm{~h}\end{array}$ \\
\hline $\mathrm{d}$ & $\begin{array}{c}\text { Factor } 1 \text { (Seed maturity): } \mathrm{S} 1=\text { milky ripe, } \mathrm{S} 2=\text { wax ripe, and } \mathrm{S} 3=\text { full ripe } \\
\text { Factor } 2 \text { (Seed storage time): } \mathrm{C} 1=0, \mathrm{C} 2=1, \mathrm{C} 3=2, \mathrm{C} 4=3, \text { and } \mathrm{C} 5=4 \text { month }\end{array}$ \\
\hline $\mathrm{e}$ & $\begin{array}{c}\text { D1 = } 1000 \mathrm{mg} \mathrm{L} \mathrm{L}^{-1} \mathrm{ABA} ; \mathrm{D} 2=500 \mathrm{mg} \mathrm{L}^{-1} \mathrm{ABA} ; \mathrm{D} 3=250 \mathrm{mg} \mathrm{L}^{-1} \mathrm{ABA} ; \mathrm{D} 4=100 \mathrm{mg} \mathrm{L}^{-1} \\
\text { ABA; D5 = } 100 \mathrm{mg} \mathrm{L}^{-1} \mathrm{GA} 3+100 \mathrm{mg} \mathrm{L}^{-1} \mathrm{ABA} ; \mathrm{D} 6=100 \mathrm{mg} \mathrm{L}^{-1} \mathrm{GA} 3+250 \mathrm{mg} \mathrm{L}^{-1} \\
\text { ABA; D7 = } 100 \mathrm{mg} \mathrm{L}^{-1} \mathrm{GA} 3+500 \mathrm{mg} \mathrm{L} \mathrm{LBA}^{-1} \mathrm{AB} ; \mathrm{D} 8=100 \mathrm{mg} \mathrm{L}^{-1} \mathrm{GA} 3+1000 \mathrm{mg} \mathrm{L}^{-1} \\
\text { ABA; CK use distilled water as control }\end{array}$ \\
\hline
\end{tabular}

